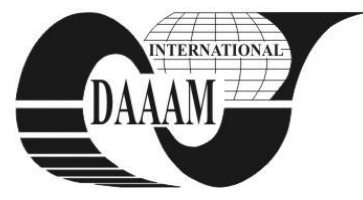

\title{
INTERNET SALES DIFFUSION DETERMINANTS: EMPIRICAL EVIDENCE FROM EU COUNTRIES
}

\author{
SIMICEVIC, V[anja]
}

\begin{abstract}
Aim of the paper is to research to what extent Internet sales by individuals is influenced by the barriers people perceive to buying/ordering over the Internet, using of Internet, and level of computer/Internet skills them posses. Eurostat database is used as a data source and multiple linear regression model is applied for investigating the research question. Following relationships have been found to be statistically significant for the percentage of the individuals who bought goods/services over the Internet within last 3 months: giving personal details over the Internet, level of necessary computer usage skills, and lack of necessary computer usage skills.
\end{abstract}

Key words: online sale, Internet, European Union, regression analysis

\section{INTRODUCTION}

The Internet is causing significant changes in the business models in all of the industry sectors and all of the business aspects. Altough at the beginning of Internet usage (middle 90s), firms were less likely to implement Internet as a sales channel (Palmer \& Griffith, 1998), and customers were less likely to buy goods over the Internet. Within the last decade Internet sales have become widely accepted business model in many fields (Cheng et al., 2006; Ruiz-Mafe et al., 2009). Many researches have investigated the barriers to buying over the Internet (Cunningham et al., 2005; Davis, 1989). The aim of this paper is to research to what extent Internet sales by individuals from EU countries is influenced by the perceived barriers, computer skills, Internet skills and level of Internet usage. On the base of this founding we define expectations related with results of this research: (1) Hypothesis 1: Buying over the Internet is influenced by the level of individuals' skills; (2) Hypothesis 2: Buying over the Internet is influenced by the level of perceived barriers to buying/ordering over the Internet.

\section{RESEARCH METHODOLOGY AND SAMPLE CHARACTERISTICS}

Eurostat database is used as a source for information for the research within the chapter of Information-Communication Technology. Data is collected according to the Eurostat model for the Community Survey on ICT usage in households and by individuals 2009 (Eurostat, 2009). Multiple linear regression model is used for testing the hypothesis of this work. As dependent variable percentage of individuals who used Internet for buying goods and/or services within last 3 months is used. As independent variables following are used: (1) perceived barriers are used for analysis (No need; Relevant information about goods and services difficult to find on website; Lack the necessary skills; It's too expensive; Too long delivery times; Problematic to receive the ordered goods at home; Worried about giving personal details over the Internet; Worried about giving credit card or personal details over the Internet; Speed of the Internet connection is too low); (2) level of computer skills (Individuals who have used a mouse to launch programs such as an Internet browser or word processor); (3) level of Internet skills (Individuals who have used a search engine to find information), and (4) Level of Internet usage (Individuals who used Internet within last 12 months).

\section{EMPIRICAL RESULTS}

Number of On-line shoppers is increasing constantly. The reasons are in the increase of Internet users, the rich offer of wide range of products and services over the high-quality designed web-sites and increasing percentage of females shopping on-line. The habits of using Internet and related skills were investigated by the calculating descriptive statistics (mean and standard deviation). The same analysis was conducted for perceived barriers to buying/ordering over the Internet and made their last online purchase within last three months. The average percentage of individuals who bought over the Internet over the last 3 months, with basic computer skills, with basic Internet skills, and who used Internet over the last 12 months are presented in Table 1. Table 2. presents average percentage of individuals who perceive barriers for buying/ordering goods over the Internet. The largest perceived barriers to buying/ordering over the Internet are worries about giving personal details over the Internet $(22,8 \%)$ and lack of the necessary skills $(21,7 \%)$.

\begin{tabular}{|l|r|r|}
\hline & Mean & St.Dev \\
\hline $\begin{array}{l}\text { Percentage of individuals who bought } \\
\text { over the Internet over the last 3 months }\end{array}$ & 25,0 & 18,4 \\
\hline $\begin{array}{l}\text { Percentage of individuals with basic } \\
\text { computer skills }\end{array}$ & 64,0 & 18,4 \\
\hline $\begin{array}{l}\text { Percentage of individuals with basic } \\
\text { Internet skills }\end{array}$ & 58,0 & 16,7 \\
\hline $\begin{array}{l}\text { Percentage of indivduals who used } \\
\text { Internet over the last 12 monhts }\end{array}$ & 64,6 & 17,2 \\
\hline
\end{tabular}

Tab. 1. Habits of using Internet and related skills

\begin{tabular}{|l|r|r|}
\hline $\begin{array}{l}\text { Perceived barriers to buying/ordering over } \\
\text { the Internet }\end{array}$ & Mean & St.Dev \\
\hline No need & 5,0 & 3,4 \\
\hline $\begin{array}{l}\text { Relevant information about goods and } \\
\text { services difficult to find on website }\end{array}$ & 3,2 & 3,2 \\
\hline Lack the necessary skills & 21,7 & 11,0 \\
\hline It's too expensive & 3,9 & 2,8 \\
\hline Too long delivery times & 10,3 & 6,8 \\
\hline $\begin{array}{l}\text { Problematic to receive the ordered goods } \\
\text { at home }\end{array}$ & 11,6 & 7,0 \\
\hline $\begin{array}{l}\text { Worried about giving personal details } \\
\text { over the Internet }\end{array}$ & 22,8 & 9,7 \\
\hline $\begin{array}{l}\text { Worried about giving credit card or } \\
\text { personal details over the Internet }\end{array}$ & 5,6 & 2,9 \\
\hline $\begin{array}{l}\text { Speed of the Internet connection is too } \\
\text { low }\end{array}$ & 3,7 & 3,5 \\
\hline
\end{tabular}

Tab. 2. Perceived barriers to buying/ordering over the Internet 
Pearson correlation coefficients between buying over the Internet over the last 3 months and other factors examined are presented in Table 3.

As expected, perceived barriers influence percentage of individuals that bought goods/services over the Internet over the last 3 months in negative manner, but only three of the barriers have found to be statistically significant (No need, Lack of the necessary skills, Worried about giving personal details over the Internet).

\begin{tabular}{|l|r|r|}
\hline & $\begin{array}{l}\text { Pearson } \\
\text { correlation }\end{array}$ & $\begin{array}{l}\text { Sig } \\
\text { (two- } \\
\text { tailed) }\end{array}$ \\
\hline No need & $-0,540^{* *}$ & 0,003 \\
\hline $\begin{array}{l}\text { Relevant information about goods } \\
\text { and services difficult to find on } \\
\text { website }\end{array}$ & $-0,121$ & 0,549 \\
\hline Lack the necessary skills & $-0,610^{* *}$ & 0,000 \\
\hline It's too expensive & $-0,028$ & 0,887 \\
\hline Too long delivery times & $-0,107$ & 0,336 \\
\hline $\begin{array}{l}\text { Problematic to receive the ordered } \\
\text { goods at home }\end{array}$ & $-0,532^{* *}$ & 0,574 \\
\hline $\begin{array}{l}\text { Worried about giving personal } \\
\text { details over the Internet }\end{array}$ & $-0,120$ & 0,002 \\
\hline $\begin{array}{l}\text { Worried about giving credit card } \\
\text { or personal details over the } \\
\text { Internet }\end{array}$ & $-0,223$ & 0,537 \\
\hline $\begin{array}{l}\text { Speed of the Internet connection } \\
\text { is too low }\end{array}$ & $0,865^{* *}$ & 0,000 \\
\hline $\begin{array}{l}\text { Percentage of individuals with } \\
\text { basic computer skills }\end{array}$ & $0,835^{* *}$ & 0,000 \\
\hline $\begin{array}{l}\text { Percentage of individuals with } \\
\text { basic Internet skills }\end{array}$ & $0,881^{* *}$ & 0,000 \\
\hline $\begin{array}{l}\text { Percentage of indivduals who } \\
\text { used Internet over the last 12 } \\
\text { monhts }\end{array}$ & & \\
\hline
\end{tabular}

Tab. 3. Pearson correlation coefficients between variables buying over the Internet over the last 3 months and other factors examined

**Correlation is significant at the 0.01 level (2-tailed)

*Correlation is significant at the 0.05 level (2-tailed)

According to the results of correlation analysis there is a positive correlation between percentage of individuals that bought goods/services over the Internet over the last 3 months and level of computer skills, level of Internet skills and Internet usage over the last 12 months.

In order to explain buying over the Internet by the perceived barriers and level of knowledge (computer and Internet skills), and Interent usage, multiple regression model was designed with the percentage of employees that bought goods over the Internet over the last 3 months as independent variable. Results are presented in the Table 4. where estimated values for regression parameters are presented with $\mathrm{p}$-values in the parenthesis.

The data fit the model rather well (Adjusted R-Squared = 0.936), what indicates highly representative regression model and two parameter estimates for the perceived battiers to buying/ordering over the Internet (Worried about giving personal details over the Internet, Lack the necessary skills) are statistically significant at $1 \%$ level. Level of computer skills is also found to be statistically significant at $1 \%$ level.

Impact of the perceived barriers that are found to be statistically significant is negative, while the impact of the computer skills is found to be positive. Those results confirm the research of the Cunningham et al. (2005) that stress the influence of the perceived risk and the consumer buying process of Internet airline reservations. Similar conclusions have been found by Cheng et al. (2006).

\begin{tabular}{|l|r|}
\hline & $\begin{array}{r}\text { Regression } \\
\text { coefficients }\end{array}$ \\
\hline Constant & 2,048 \\
\hline No need & $-0,381$ \\
\hline $\begin{array}{l}\text { Relevant information about goods and } \\
\text { services difficult to find on website }\end{array}$ & 0,289 \\
\hline Lack the necessary skills & $-0,382^{* *}$ \\
\hline It's too expensive & 0,000 \\
\hline Too long delivery times & $-0,485$ \\
\hline $\begin{array}{l}\text { Problematic to receive the ordered goods at } \\
\text { home }\end{array}$ & 0,741 \\
\hline $\begin{array}{l}\text { Worried about giving personal details over } \\
\text { the Internet }\end{array}$ & $-0,667 * *$ \\
\hline $\begin{array}{l}\text { Worried about giving credit card or } \\
\text { personal details over the Internet }\end{array}$ & 0,686 \\
\hline Speed of the Internet connection is too low & 0,373 \\
\hline $\begin{array}{l}\text { Percentage of individuals with basic } \\
\text { computer skills }\end{array}$ & 0,092 \\
\hline $\begin{array}{l}\text { Percentage of individuals with basic } \\
\text { Internet skills }\end{array}$ & $-0,431$ \\
\hline $\begin{array}{l}\text { Percentage of indivduals who used Internet } \\
\text { over the last } 12 \text { monhts }\end{array}$ & $1,119^{* *}$ \\
\hline Adjusted R-square & 0,936 \\
\hline
\end{tabular}

Tab. 4. Results of linear regression model

** Statistically significant at $1 \%$ level

\section{CONLUSION}

Internet usage is widely accepted among EU countries' citizens. However, there is still significant influence of the perceived barriers for the buying/ordering goods over the Internet, and the level of computer/Internet skills. Multiple linear regression model is used for the analysis and relationships have been found to be statistically significant for the percentage of the individuals who bought goods/services over the Internet within last 3 months: Worried about giving personal details over the Internet, Lack the necessary skills, Level of computer skills. Due to the wide use of Internet, usage of Internet did not have statistically significant influence. Based on our results both hypothesis of the paper can be accepted, thus confirming that buying over the Internet in EU countries is influenced both by the level of individuals' skills and the level of perceived barriers.

\section{REFERENCES}

Cheng, J.M.S.; Sheen, G.J. \& Lou, G.C. (2006). Consumer acceptance of the Internet as a channel function perspective. Technovation, Vol. 26, No. 7, (July 2006) pp. 753-894, ISSN 0166-4972

Cunningham, L.F.; Gerlach, J.H.; Harper, M.D. \& Young C. E (2005). Perceived risk and the consumer buying process: Internet airline reservations. International Journal of Service Industry Management Vol.16, No.4, (April 2005), pp. 357-372, ISSN 1757-5818

Davis, F.D. (1989). Perceived Usefulness, Perceived Ease of Use, and User Acceptance of Information Technology. MIS Quarterly Vol.13, No.3, (September 1989), pp. 319-340, ISSN 1540-1960

Eurostat (2009). Community survey on ICT usage in households and by individual, Available from http://circa.europa.eu/ Accessed: 2011-03-04

Palmer, J.W. \& Griffith, D. (1998). An emerging model of Web site design for marketing. Communications of ACM, Vol. 41, No. 3, (March 1998), pp. 44-51, ISSN 0001-0782

Ruiz- Mafé, C.; Sanz-Blas, S. \& Aldás-Manzano, J. (2009). Drivers and barriers to online airline ticket purchasing. Journal of Air Transport Management, Vol.15, No. 1, (January 2009), pp. 294-298, ISSN 0969-6997 